UDK $630 * 54: 582.475(497.6)$

\title{
SELECTION OF REGRESSION MODELS FOR GRAPHICALLY DETERMINED SITE CLASS CURVES FOR FIR IN UNEVEN-AGED STANDS IN BOSNIA AND HERCEGOVINA
}

\author{
Izbor matematičkih modela za grafički utvrđene bonitetne krive za jelu u raznodobnim \\ sastojinama u Bosni i Hercegovini
}

Besim Balić $^{1}$, Aida Ibrahimspahić ${ }^{1}$, Ahmet Lojo ${ }^{1}$, Admir Avdagić ${ }^{1}$

\begin{abstract}
In expert activities of forest managements, the forest stand volume is most frequently determined by way of volume tables, the so-called management tariffs. For an evaluation of stand volume using this method, the method of volume tables, it is necessary to know the site class (rating) of the stand for present tree species that is used as an argument for the selection of suitable volume progression (management tariff). The site quality for certain species in mixed stands is determined by comparing the height of trees at certain diameters at breast height ( $\mathrm{dbh}$ ) with the height of appropriate dispositions of height site class curves. In so doing the focus is placed on the ratio between the heights of large diameter trees, and the quality of the stand is rated within an interval of more defined site quality classes. For the purposes of a more objective and simpler assessment of site quality, there have recently been attempts to make site quality assessments mathematically, using appropriate formulas in which tree heights or average heights by diameter classes and heights determined by mathematical functions of site class curves are used. For economically important tree species in Bosnia and Herzegovina (fir, spruce, beech, sessile oak, black pine and scots pine), the dispositions of height site class curves (and classes) are constructed graphically and mathematical functions for them are not known. A large number of mathematical models that are often used to represent growth trends and that satisfy the needs of height curves is analyzed in this paper with a view to determining the most suitable regression model for simulating height site class curves for fir in high forests in Bosnia and Herzegovina. The expanded Prodan model (with an additional item in the denominator) has been selected as the most suitable one on the basis of statistical indicators of the regression model quality.
\end{abstract}

Key words: fir, site quality, height site class disposition, regression models, stand volume

\footnotetext{
${ }^{1}$ Faculty of Forestry, University of Sarajevo, Bosnia and Hercegovina
} 


\section{INTRODUCTION - Uvod}

One of the arguments (input values) in evaluating the stand volume of certain tree species using the method of volume tables for the selection of appropriate volume table (management tariff) is the site quality rating. For economically important tree species of mixed stands in Bosnia and Herzegovina, dispositions of site quality classes have been determined for as follows: fir, spruce and beech (MATIĆ, 1959); for black pine (DRINIĆ, 1963); for scots pine (STOJANOVIĆ, 1966) and for sessile oak (VUKMIROVIĆ, 1963). Dispositions of 5 site quality classes have been developed for each of the said tree species. The total width of variability of the height of trees of each diameter class was divided, using the banding method (BAUR, 1984) into 5 parts (belts) of equal width, after which continuous curves, i.e. site class curves of tree heights, were drawn graphically through the means of the said belts. The said curves are of sigmoid shape and they satisfy the criteria defined by mathematical characteristics of height curves (BANKOVIĆ and PANTIĆ, 2006; PRANJIĆ and LUKIĆ 1997). However, since there is no adequate statistical measure for error assessment for the graphical method of construction of height curves (data flattening), many authors see this method as subjective (IBRAHIMSPAHIĆ, 2004; BALIĆ, 2006).

Site quality assessment for a tree species in a specific stand is conducted by comparing the height curve, which is constructed on the basis of measured diameters at breast height (dbh) and heights (h) of trees, with the corresponding disposition of site class curves. In so doing, the position of the height curve within the site class bundle is analyzed and an assessment (rating) is made which belt, i.e. site class, belongs the site of stand for the given species.

Difficulties often occur in assessing the site quality, because height curves often cut through two or more site class belts. For such cases, and for the purposes of a more objective quality assessment, FLURY, (according to MATIĆ, 1980) proposes that focus should be placed on the position of the portion of the height curve that relates to higher diameter classes. Moreover, FLURY (1933), stresses, referring to the uncertainty of the existing site quality assessment methods in selection forests, that site quality assessment on the basis of tree heights is only possible in cases of forests in which selection managements has been duly implemented for a long time (according to MILETIĆ, 1950). Site quality assessment has in recent years been done mathematically. The so-called partial site class of each tree is determined using appropriate formulas on the basis of the measured dbh and height of trees just like appropriate values according to regression models of height curves. Stronger influence of heights of larger diameter treesthat are not influenced by shading but reflect the site conditions, is ensured through the use of weighting factors, volume (LOJO, 2011) or tree basal area (BALIĆ et al 2007; BALIĆ, 2011; IBRAHIMSPAHIĆ, 2013). This is in accordance with the recommendation given on the basis of results of researches of tree height dynamics (height curves) as a result of changed structure of mixed stands of beech, fir and spruce, that only the heights of larger diameter trees $\left(D_{1,3} \approx 50 \mathrm{~cm}\right)$ need to be measured and used for a site quality assessment (IBRAHIMSPAHIĆ, 2013). 
Besides, measuring of the minimum number of those height representatives is recommended, based on which a reliable assessment of site quality of certain tree species in mixed stands can be made (AVDAGIĆ, 2013).

The application of mathematical method in site quality assessment for certain tree species using the existing dispositions of site class curves requires knowledge of their mathematical functions. The research issue of this paper is the question of which regression model is the most suitable one for simulating height site class curves for fir in high forests of Bosnia and Herzegovina as constructed by graphical method.

\section{The aim and objectives of research}

The objective of this research is to find the most suitable regression model for a correct presentation of height site class disposition for fir in high forests in Bosnia and Herzegovina as determined by a graphical method, which will be used in the algorithm for so-called mathematical determination of site quality. To achieve the set aim it is necessary to solve the following tasks:

$>$ take series of data for tree diameters and heights from appropriate taxation elements tables for fir (DRINIĆ et al. 1990) for all five site quality classes,

$>$ check adequacy of functions (mathematical models) that are most frequently used in the regression analysis while presenting the dependence of tree height on their dbh, and

$>$ test the validity of the regression model with the most suitable statistical indicators (correlation coefficient, determination coefficient, standard regression error and coefficient of variability of the dependent variable estimation) for all site quality classes using an appropriate statistical test.

\section{MATERIAL AND METHODS - Materijal i metode}

Data on fir tree heights and dbh for all five site quality classes from the fir volume tables were used as a starting base for the implementation of these researches (DRINIĆ et al. 1990). The said table values were determined by a simple reading of data pairs from graphically constructed disposition of site class height curves for fir (MATIC, 1959). The following statistical methods were used in the research: descriptive analysis, simple non-linear regression (Nonlinear Estimation), testing of significance of difference between means of dependent samples. Ratings and selection of the best regression model based on statistical indicators of the strength of correlation $\left(\mathrm{R}^{2}\right.$ - determination coefficient and $\mathrm{R}$ - correlation coefficient) and assessment accuracy $\left(\mathrm{S}_{\mathrm{ey}}\right.$ - standard regression error and $K V_{\hat{y}}$ - coefficient of variability of the dependent variable estimation) (ČABARAVDIĆ, 2017).

Statistical software application Statistica 8.0. was used for the implementation of the said statistical analyses, while MS Excel 2007 application was used for simpler analyses and graphs. 


\section{RESULTS AND DISCUSSION- Rezultati i diskusija}

Numerical series of data pairs dbh and h taken from volume tables for each height site quality class define (represent) means of site quality classes (belts), and are marked with indexes (ratings): 1, 2, 3, 4 and 5. Index 1 means the best site class (biggest height), while 5 means the worst one (lowest heights). Boundaries between specific site quality classes run at half a distance between the means, they are determined by simple mathematical operations (addition, subtraction, division) and are marked with indexes 1,$5 ; 2,5 ; 3,5$ and 4,5 . The upper limit of the first site quality class and the lower limit of the fifth one essentially do not exist, but they are positioned for the needs of application of the mathematical method of site quality assessment just like other boundaries, at the distance of half a width of site quality class from the mean. The upper limit of the first site quality class is marked with 0,5 , and the lower limit of the fifth one with 5,5. The said boundaries limit the tree height variation interval within the scope of specific site quality classes and the entire site class dispositions at a specific dbh. This way, the entire fir height variation belt is divided into the so called partial site quality classes where 11 site quality classes were obtained: 0,$5 ; 1 ; 1,5 ; 2 ; 2,5 ; 3 ; 3,5 ; 4 ; 4,5 ; 5$; and 5,5 .

\section{Regression Analyses of the Fir Tree Height and DBH}

In order to find the „best” regression model to present the dependence of fir tree height on their dbh, several dendometric functions that are often used for these purposes were analyzed (KRAMER and AKÇA, 2003). The following models were tested:

1. Second degree parabola

$$
H_{0}=1,3+a \cdot D_{1,3}+b \cdot D_{1,3}^{2}
$$

2. Mihajlov's function

$$
H_{0}=1,3+a \cdot e^{-b / D_{1,3}}
$$

3. Levakovic's function

$$
H_{0}=1,3+e^{a}\left(\frac{D_{1,3}}{D_{1,3}+1}\right)^{b}
$$

4. Prodan's function

$$
H_{0}=1,3+\frac{D_{1,3}^{2}}{\left(a+b \cdot D_{1,3}+c \cdot D_{1,3}{ }^{2}\right)}
$$

5. Petterson's function

$$
H_{0}=1,3+\left(\frac{D_{1,3}}{a+b \cdot D_{1,3}}\right)^{2}
$$

The obtained values of the used statistical indicators for evaluation and selection of the best regression model for all tested models are given in the in Table 1. 
Table 1. Values of statistical indicators of the strength of correlation and assessment accuracy of tested regression models .

Tabela 1.Veličine statističkih pokazatelja jačine korelacione veze i preciznosti procjene testiranih regresionih modela

\begin{tabular}{|ll|c|c|c|c|}
\hline & Name of tested model & $\mathrm{R}^{2}$ & $\mathrm{R}$ & $\mathrm{S}_{\mathrm{ey}}(\mathrm{m})$ & $K V_{\hat{y}}(\%)$ \\
\hline 1. & Second degree parabola & 0.983 & 0.992 & 0.95 & 3.83 \\
\hline 2. & Mihajlov's function & 0.993 & 0.997 & 0.61 & 2.46 \\
\hline 3. & Levaković's function & 0.993 & 0.996 & 0.62 & 2.50 \\
\hline 4. & Prodan's function & 0.998 & 0.999 & 0.32 & 1.29 \\
\hline 5. & Petterson's function & 0.984 & 0.992 & 0.92 & 3.70 \\
\hline $\begin{array}{l}\text { 6. } \\
\text { Expanded Prodan's } \\
\text { function }\end{array}$ & 0.999 & 0.999 & 0.18 & 0.71 \\
\hline
\end{tabular}

Values provided in Table 1 suggest that selection of any of the analyzed models for simulating site class curves for fir would be a sort of an error, but that the least error would be if model (6), expanded Prodan's function, is selected. This model, unlike the basic Prodan's model, has an additional item in the denominator of fraction with the dbh with cubic exponent. The general form of this mathematical model is as follows:

$$
H=1,3+\frac{D_{1,3}^{2}}{a+b \cdot D_{1,3}+c \cdot D_{1,3}^{2}+d \cdot D_{1,3}^{3}}
$$

This model was used in the regression of all 11 site class curves. The values of $a, b, c$ and $d$, parameters for each site class curve $\left(H_{0,5}-H_{5,5}\right)$ were determined by the method of non-linear regression (Nonlinear Estimation) using Statistica 8.0, software, and their values are provided in Table 2.

Table 2. Values of parameters ( $a, b, c$ and $d$ ) of the regression models of all site class curves

$\left(H_{0,5}-H_{5}\right.$

Tabela 2. Veličine parametara $(a, b, c i d)$ regresionih modela svih bonitetnih krivih $\left(H_{0,5}-\right.$ $\mathrm{H}_{5,5}$ )

\begin{tabular}{|c|c|c|c|c|c|c|c|c|c|c|c|}
\hline \multirow{2}{*}{$\begin{array}{c}\text { Function } \\
\text { parameters }\end{array}$} & \multicolumn{10}{|c|}{ Height site class } \\
\cline { 2 - 13 } & H_0,5 & H_1 & H_1,5 & H_2 & H_2,5 & H_3 & H_3,5 & H_4 & H_4,5 & H_5 & H_5,5 \\
\hline $\boldsymbol{a}$ & 10.1451 & 10.2269 & 10.5370 & 10.8617 & 10.5629 & 10.1337 & 9.8704 & 9.4610 & 8.9430 & 8.1878 & 7.1168 \\
\hline $\boldsymbol{b}$ & 0.3593 & 0.3949 & 0.4109 & 0.4280 & 0.5082 & 0.6044 & 0.6881 & 0.7885 & 0.9141 & 1.0675 & 1.2563 \\
\hline $\boldsymbol{c}$ & 0.0164 & 0.0170 & 0.0182 & 0.0195 & 0.0196 & 0.0196 & 0.0205 & 0.0215 & 0.0225 & 0.0237 & 0.0251 \\
\hline $\boldsymbol{d}$ & 0.00003 & 0.0000 & 0.0000 & 0.0000 & 0.0001 & 0.0001 & 0.0001 & 0.0001 & 0.0001 & 0.0001 & 0.0001 \\
\hline
\end{tabular}




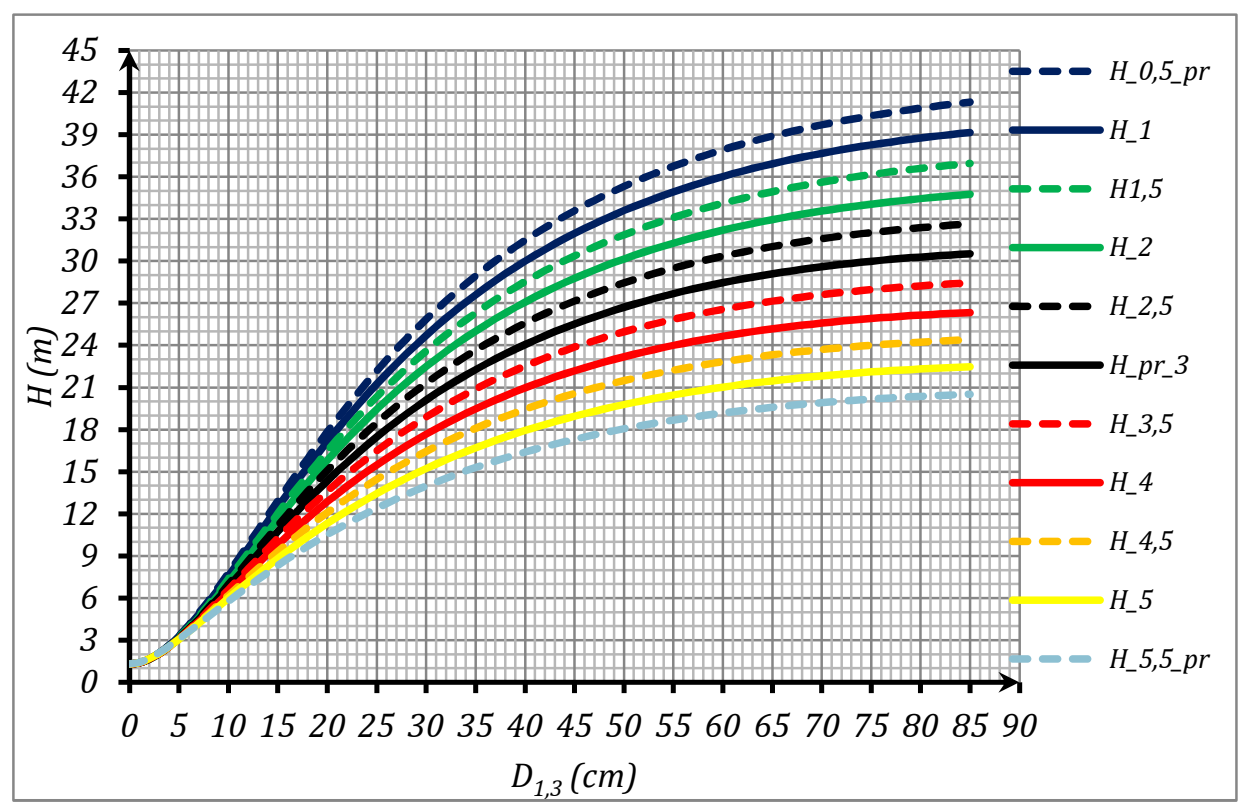

Graph 1. Height site class disposition for fir on the basis of the selected regression model Grafikon 1. Visinska bonitetna dispozicija za jelu na bazi odabranog regresionog modela

Testing of Statistical Significance of Differences between Heights of Fir Trees estimated using the selected Regression Models and Heights from Tables

After regression models for simulating site class curves for fir were determined, an analysis was made of the degree of coincidence of shapes of determined models with corresponding height site class curves according to data from tables (volume tariffs) (DRINIĆ et al. 1990) and statistical significance of the existing differences was tested.

Graph 2 provides graphical views of site class curves (site quality class means) determined by selected functions (f) and determined on the basis of data from tables ( $\mathrm{t})$. 


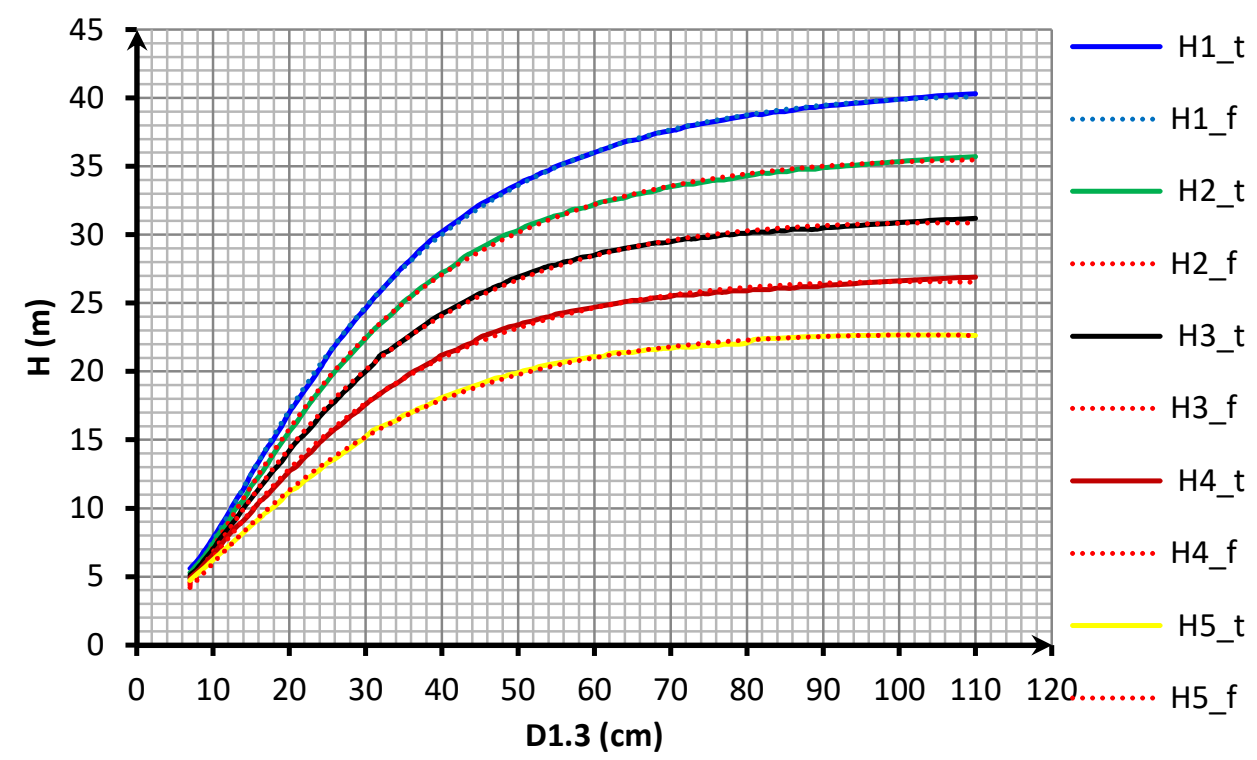

Graph 2. Degree of coincidence of site class curves shapes determined by the selected function with the existing disposition of site class curves for fir.

Grafikon 2. Stepen saglasnosti oblika bonitenih krivih utvrđenih po odabranoj funkciji sa postojećom dispozicijom bonitetnih krivih za jelu

A slight discrepancy is visible in the diagram above, i.e. a great degree of coincidence of the provided site class curves within the entire interval of empirical data.

The coincidence, i.e. statistical significance of differences in tree heights taken from the tables and the heights determined for the same diameter on the basis of the selected models was verified by way of a statistical t-test for dependent sample means ( $t$-Test: Paired Two Sample for Means). The testing was done by site quality classes (from I to V), and the results are provided in Table 3.

Given the fact that the measured t-test values for all included site quality classes are considerably lower compared to the appropriate table critical values, it suggests that there are no statistically significant differences between the tested (pairs) heights in the domain of dbh from 7 up to $110 \mathrm{~cm}$ for all five site class curves, with the level of confidence of $95 \%$. This means that the selected models of height site class curves correctly simulate the existing height site class curves for fir in pure and mixed stands in Bosnia and Herzegovina 
Table 3. - T-test results of dependent sample means (t-Test: Paired Two Sample for Means) for all height site quality classes (I-V)

Tabela 2. - Rezultati t-testa sredina zavisnih uzoraka (t-Test: Paired Two Sample for Means) za sve visinske bonitetne razrede (I-V)

\begin{tabular}{|c|c|c|c|c|c|c|c|c|c|c|}
\hline Statistical parameters & $H-I \_t$ & $\begin{array}{l}H- \\
I f\end{array}$ & $\begin{array}{l}H- \\
I I+t\end{array}$ & $\begin{array}{l}H- \\
I I f\end{array}$ & $\begin{array}{c}H- \\
I I I \_t\end{array}$ & $\begin{array}{c}H- \\
I I I f\end{array}$ & $\begin{array}{l}H- \\
I V_{-} t\end{array}$ & $\begin{array}{l}H I V \\
f\end{array}$ & $\begin{array}{l}H_{-} \\
V_{-} t\end{array}$ & $\begin{array}{l}H- \\
V f\end{array}$ \\
\hline \multirow{2}{*}{ Mean } & 31.3 & 31.3 & 28.0 & 28,0 & 24.8 & 24,8 & 21.5 & 21.5 & 18.5 & 18.4 \\
\hline & 6 & 5 & 7 & 6 & 2 & 1 & 8 & 7 & 0 & 9 \\
\hline \multirow{2}{*}{ Variance } & 98.4 & 98.9 & 74.1 & 74,6 & 54.3 & 54,6 & 38.0 & 38.2 & 26.0 & 26.2 \\
\hline & 6 & 9 & 7 & 4 & 1 & 3 & 5 & 8 & 8 & 0 \\
\hline Number of observations & 104 & 104 & 104 & 104 & 104 & 104 & 104 & 104 & 104 & 104 \\
\hline \multirow{2}{*}{$\begin{array}{l}\text { Pearson Correlation } \\
\text { coefficient }\end{array}$} & 0.99 & & 0.99 & & 0.99 & & 0.99 & & 0.99 & \\
\hline & 98 & & 98 & & 95 & & 95 & & 96 & \\
\hline $\begin{array}{l}\text { Hypothesized Mean } \\
\text { Difference }\end{array}$ & 0 & & 0 & & 0 & & 0 & & 0 & \\
\hline$D f$ - degrees of freedom & 103 & & 103 & & 103 & & 103 & & 103 & \\
\hline t Stat & 0.61 & & 0.56 & & 0.43 & & 0.34 & & 0.54 & \\
\hline $\mathrm{P}(\mathrm{T}<=\mathrm{t})$ one-tail & 0.27 & & 0.29 & & 0.33 & & 0.37 & & 0.30 & \\
\hline t Critical one-tail & 1.66 & & 1.67 & & 1.66 & & 1.66 & & 1.66 & \\
\hline $\mathrm{P}(\mathrm{T}<=\mathrm{t})$ two-tail & 0.54 & & 0.58 & & 0.67 & & 0.74 & & 0.59 & \\
\hline t Critical two-tail & 1.98 & & 1.98 & & 1.98 & & 1.98 & & 1.98 & \\
\hline
\end{tabular}

Legend

$\mathrm{H}-\mathrm{I} \_\mathrm{t}-\mathrm{H}-\mathrm{V} \_\mathrm{t}$ heights read form the tables for the given site quality class (site quality class from $\mathrm{I}$ to $\mathrm{V}$ )

$H-I \_t-H-V \_t$ visine očitane iz tablica za dati bonitetni razred (od I do V bonitetnog razreda) $\mathrm{H}-\mathrm{I}_{-} \mathrm{f}-\mathrm{H}-\mathrm{V}_{-} \mathrm{f}$ heights calculated on the basis of the selected model for the given site quality class (site quality class from I to $\mathrm{V}$ ).

$H-I f-H-V$ f visine izračunate na osnovu izabranog modela za dati bonitetni razred (od I do $V$ bonitetnog razreda).

\section{CONCLUSION - Zaključak}

In accordance with the set research aim that was achieved through solving of the defined tasks the solutions of which are contained in the provided results of this research, the following conclusions may be made:

- It has been established through an analysis of more different regression models for construction of set class curves for fir that the most "suitable" model for all site quality classes is similar to the Prodan's function, but with one difference and that is an additional item added to the function denominator with third power of the $\mathrm{dbh}$. 
- Regression models for all five site quality classes just like for the so-called partial site quality classes for fir, 11 site class curves in total, were determined according to the selected model.

- The determined models of height cite class curves for fir are good simulators of previously constructed (actual) height site class curves and their application in practical work is recommended in mathematical determination of height site classes.

- Application of the determined models of height site class curves enables full automation of the site quality assessment procedure for this species of trees and may, as required, be installed in a software application for processing taxation data for preparation of forest management plans.

The offered approach in the mathematical assessment of site quality objectifies to a great extent the evaluation of the fir tree volume if the method of management tariffs is applied for this purpose.

Due to the actuality of solving of the problem of site quality assessment, search for suitable models needs to continue for other economically significant tree species for which site quality assessment is still carried out using the graphical method, and for which volume tables (management tariffs) have been developed and are widely applied for the assessment of taxation elements of mixed stands

\section{REFERENCES - Literatura}

KRAMER, H., AKÇA, A. (2008): Leitfaden zur Waldmesslehre. J.D.Sauerländer's Verlag.5. erweiterte Auflage. Frankfurt am Main.

AVDAGIĆ, A. (2013): Unapređenje plana uzorka za procjenu boniteta staništa na osnovu visina stabala u šumama bukve, jele sa smrčom na krečnjacima. Magistarski rad. Šumarski fakultet Univerzitet u Sarajevu. Str.1-103

BALIĆ, B. (2003): Bonitiranje jednodobnih zasada bijelog bora (Pinus sylvestris L.) na karbonatnim supstratima u Bosni. I Simpozij poljoprivrede, veterinarstva i šumarstva. Neum. Zbornik radova Šumarskog fakulteta u Sarajevu.

BALIĆ, B., LOJO, A., IBRAHIMSPAHIĆ, A. (2007): Utvrđivanje bonitetne dispozicije staništa izdanačkih šuma bukve na području Kantona Sarajevo. Radovi Šmarskog fakulteta u Sarajevu. Radovi Šumarskog fakulteta u Sarajevu. No.1, str 67-79.

BALIĆ, B. (2011): Proizvodnost, strukturna izgrađenost i modeli rasta i prirasta izdanačkih šuma bukve na području Kantona Sarajevo". Doktorska disertacija. Šumarski fakultet Univerziteta u Sarajevu. Str.1-203.

BANKOVIĆ, S., PANTIĆ, D. (2006): Dendrometrija. Šumarski fakultet Univerziteta u Beogradu. Str.1-256. 
BAUR, F. (1894): Die Holzmesskunde, 4., Aufl., Wien.

DRINIĆ, P. (1963): Taksacione osnove za gazdovanje šumama crnog bora u Bosni.

Radovi Šumarskog fakulteta i Instituta za šumarstvo, Sarajevo. Br 8. str. 147-228.

ČABARAVDIĆ, A. (2017): Biometrika u šumarstvu i hortikulturi. Knjiga. Šumarski Fakultet Sarajevo.

DRINIĆ, P., MATIĆ,V., PAVLIĆ, J., PROLIĆ, N., STOJANOVIĆ, O., VUKMIROVIĆ, V., KOPRIVICA, M. (1990): Tablice taksacionih elemenata visokih i izdanačkih šuma u Bosni i Hercegovini. Posebno izdanje. Šumarski fakultet. 327 S.

IBRAHIMSPAHIĆ, A. (2004): Regresione analize proizvodnih karakteristika jednodobnih nenjegovanih šumskih zasada crnog bora (Pinus nigra Arn.) na karbonatnim supstratima u Bosni. Magistarski rad, mnsc. Šumarski fakultet Univerziteta u Sarajevu.

IBRAHIMSPAHIĆ, A. (2013): Prirast i razvoj sastojina bukve, jele i smrče u GJ „Igman“, doktrorska disertacija, mnsc. Šumarski fakultet Univerziteta u Sarajevu.

KRAMER, H., AKÇA, A. (2008): Leitfaden zur Waldmesslehre. J.D.Sauerländer's Verlag.5. erweiterte Auflage. Frankfurt am Main.

MILETIĆ, Ž.(1950): Osnovi uređivanja prebirne šume. Knjiga I. Beograd.

LOJO, A. (2011): Fortmiranje gazdinskih klasa unutar šuma bukve i jele i šuma bukve i jele sa smrčom na krečnjacima i dolomitima. Doktorska disretacija. Šumarski fakultet Univerziteta u Sarajevu.

MATić, V. (1959): Taksacioni elementi prebornih šuma jele, smrče i bukve na području Bosne. Radovi Šumarskog Fakulteta i Instituta za šumarstvo i drvnu industriju u Sarajevu, br.4.

PRANJiĆ, A., LUKIĆ, N. (1997): Izmjera šuma. Šumarski Fakultet Sveučilišta u Zagrebu. Str.1-410.

STOJANOVIĆ, O. (1966): Taksacione osnove za gazdovanje šumama bijelog bora u Bosni. Radovi Šumarskog fakulteta i Instituta za šumarstvo u Sarajevu. X. sveska 8.

VUKMiROViĆ, V. (1963): Prirast i drugi taksacioni elementi hrasta kitnjaka u Bosni. Radovi Šmarskog fakulteta i Instituta za šumarstvo Sarajevo, XVII. Br.8., str. 81-142.

FLURY, PH. (1933): Über die Wachstumsverhältnisse des Plenterwaldes. Mitteilungen der Schweizerischen Centralanstalt für das forstliche Versuchwessen, XVIII Band, Heft I. 


\begin{abstract}
SAŽETAK
$\mathrm{U}$ radu je prikazan postupak izbora najpovoljnijeg regresionog modela za predstavljanje zavisnosti visine stabala jele od njihovih prsnih prečnika datih za pet visinskih bonitenih razreda staništa u postojećim i aktuelnim zapreminskim tablicama za jelu (DRINIĆ et al. 1990). Analizirano je pet različitih modela, dendrometrijskih funkcija koje se često koriste za simuliranje trendova rasta stabala i šumskih sastojina kao i za konstrukciju visinskih krivih. Konstatovano je da se zbog stohastičke veze između visina i prečnika stabala odabirom bilo koje od analiziranih modela prave manje ili veće greške. Kao najpovoljniji je odabran model koji predstavlja prošrenu funkciju Prodana, kojoj je u nazivniku dodan još jedan član sa trećom potencijom prečnika. Za ovaj model su utvrđene napovoljnije veličine statističkih pokazatelja jačine korelacione veze i preciznosti procjene. Metodom jednostavne nelinerane regresije utvrđene su veličine parametara modela $(a, b, c$ i $d)$ za 11 visinskih bonitenih krivih (sredine i granice pet bonitetnih razreda; $H_{0,5}-H_{5,5}$ ). Na osnovu rezultata provedenih statističkih testiranja konstatovano je da su utvrđeni modeli visinskih bonitetnih krivih za jelu dobri simulatori prethodno konstrisanih (aktuelnih) visinskih bonitetnih krivih i preporučena je njihova primjena u praktičnom radu pri računskom određivanju visinskog boniteta. Ukazano je da se numerički (računski) postupak procjene boniteta staništa za jelu sada može automatizirati i po potrebi ugraditi u softversku aplikaciju za obradu taksacionih podataka za izradu šumskogospodarskih osnova. Na kraju rada je istaknuto da primjena računskog metoda procjene boniteta staništa u značajnoj mjeri objektivizira procjenu zapremine stabala po metodu uređajnih tarifa, kao i da je potreban nastavak iznalaženja odgovarajućih modela visinskih bonitenih krivih za ostale privredno značajnije vrste drveća za koje se bonitiranje staništa još uvijek provodi grafičkim metodom, a za njih su izrađene zapremisnke tablice - uređajne tarife i u širokoj su primjeni za procjenu taksacionih elemenata raznodobnih sastojina.
\end{abstract}

Corresponding author: Besim Balić; Faculty of Forestry University of Sarajevo, Zagrebačka 20, 71000 Sarajevo, Bosnia \& Herzegovina; e-mail: b.balic@sfsa.unsa.ba 